\title{
"The relations unshadowing in business activities: the economic and legal factors of security at the macroeconomic level"
}

\begin{tabular}{|c|c|}
\hline \multirow{5}{*}{ AUTHORS } & Anatoliy Kulish \\
\hline & Mykola Petrushenko (D https://orcid.org/0000-0003-0098-7872 \\
\hline & $\mathbb{R}$ https://publons.com/researcher/AAG-8711-2019 \\
\hline & Oleg Reznik (D) https://orcid.org/0000-0003-4569-8863 \\
\hline & Elena Kiselyova \\
\hline ARTICLE INFO & $\begin{array}{l}\text { Anatoliy Kulish, Mykola Petrushenko, Oleg Reznik and Elena Kiselyova (2018). } \\
\text { The relations unshadowing in business activities: the economic and legal factors } \\
\text { of security at the macroeconomic level. Problems and Perspectives in } \\
\text { Management, 16(1), 428-436. doi:10.21511/ppm.16(1).2018.40 }\end{array}$ \\
\hline DOI & http://dx.doi.org/10.21511/ppm.16(1).2018.40 \\
\hline RELEASED ON & Tuesday, 03 April 2018 \\
\hline RECEIVED ON & Saturday, 17 February 2018 \\
\hline \multirow[t]{2}{*}{ ACCEPTED ON } & Thursday, 22 March 2018 \\
\hline & $((c))_{\text {EY-NG }}$ \\
\hline LICENSE & $\begin{array}{l}\text { This work is licensed under a Creative Commons Attribution-NonCommercial } 4.0 \\
\text { International License }\end{array}$ \\
\hline JOURNAL & "Problems and Perspectives in Management" \\
\hline ISSN PRINT & $1727-7051$ \\
\hline ISSN ONLINE & $1810-5467$ \\
\hline PUBLISHER & LLC "Consulting Publishing Company "Business Perspectives" \\
\hline FOUNDER & LLC "Consulting Publishing Company "Business Perspectives" \\
\hline
\end{tabular}

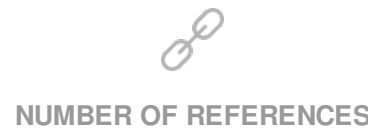

20
NUMBER OF FIGURES

2
NUMBER OF TABLES

1

(C) The author(s) 2022. This publication is an open access article. 


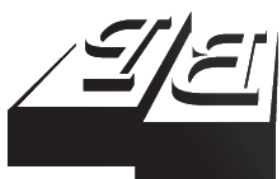

BUSINESS PERSPECTIVES

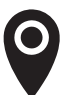

LLC "CPC "Business Perspectives" Hryhorii Skovoroda lane, 10, Sumy, 40022, Ukraine

www.businessperspectives.org

Received on: $17^{\text {th }}$ of February, 2018 Accepted on: 22nd of March, 2018

(C) Anatoliy Kulish, Mykola Petrushenko, Oleg Reznik, Elena Kiselyova, 2018

Anatoliy Kulish, Director, Educational and Scientific Institute of Law, Sumy State University, Ukraine.

Mykola Petrushenko, Assistant Professor of Department of Management, Sumy State University, Ukraine.

Oleg Reznik, Associate Professor of Department of Administrative Economic Law and Financial and Economic Security, Educational and Scientific Institute of Law, Sumy State University, Ukraine.

Elena Kiselyova, Associate Professor of Department of Administrative, Economic Law and Financial and Economic Security, Educational and Scientific Institute of Law, Sumy State University, Ukraine.

\section{(ㄷ)(1) $(9$}

This is an Open Access article, distributed under the terms of the Creative Commons Attribution-NonCommercial 4.0 International license, which permits re-use, distribution, and reproduction, provided the materials aren't used for commercial purposes and the original work is properly cited.
Anatoliy Kulish (Ukraine), Mykola Petrushenko (Ukraine), Oleg Reznik (Ukraine), Elena Kiselyova (Ukraine)

\section{THE RELATIONS UNSHADOWING IN BUSINESS ACTIVITIES: THE ECONOMIC AND LEGAL FACTORS OF SECURITY AT THE MACROECONOMIC LEVEL}

\begin{abstract}
The paper analyzes the current state of the shadow relations in business activities in Ukraine. The purpose of the article is to investigate the current state of the shadow relations in business activity in Ukraine and abroad; find out the essence of the term "the relations unshadowing in business activity", develop the suggestions, which are aimed at improving the scientific approaches to the economic and legal principles of the relations unshadowing in business activity as a factor of an influence at the macroeconomic level. The issue of sensitive motivation system creating is actualized for the purpose of the economic activities unshadowing. It is proved that it is impossible now to accurately assess the extent of the shadow economy. The economic and legal ways of improving the business unshadowing are proposed, as well as the integration of the relations unshadowing in the business activities into a system of safety factors at the macroeconomic level. Namely, the institutional and structural factors, including: an influence on the structural policy and mechanism of its implementation, possible changes in the structure of the public administration, institutional changes, management of the state corporate rights, as well as a new stage of denationalization of the property and the privatization; programmatic and strategic factors: the economic development strategy, targeted state programs, as well as the state programs of the social and economic development; financial, investment, competition, and innovation factors: the competition policy and its implementation, the state investment policy and its implementation, innovation policy and its implementation, as well as the impact on financial and economic processes in the state. Based on the research, the ways to improve the economic unshadowing issue are proposed, in particular through the introduction of changes to the existing regulatory legislation.
\end{abstract}

Keywords

JEL Classification

unshadowing, business activities, economic and legal factors, economic security

K42, M21, O17

\section{INTRODUCTION}

The percentage of the shadow business activities is increasing in the Ukrainian economy. Of course, the shadow relations in the economy, having the objective nature, exist in any country, but the task of the state is to prevent the excess of the critical level of the shadowing for safety purposes.

In order to develop and formulate the specific activities on the relations unshadowing in business activities, it is needed to study the causes of creation and existence of the shadow relations in the economy. It is necessary to define the essence of the shadow relations in business activities, analyze their present state, define foreign experience of the relations unshadowing in the economic sphere, propose, on its basis, the ways to use opportunities to prevent the excess of the critical level of the shadowing, as well as to create a sensitive system of the economic incentives at the legislative level aimed at the relations unshadowing in business activities. 


\section{LITERATURE REVIEW}

The economic and legal aspects of the shadow economy, and the relevant principles of the relations unshadowing in the business activities were explored by many foreign and Ukrainian scientists. Thus, estimations of the shadow economies are presented in the work by Schneider, Buehn, and Moutenegro (2010). Williams and Horodnic (2015) have tentatively confirmed a tax morale explanation for the shadow economy within the institutional theory. The theoretical basis of the shadow economy and economy unshadowing in Ukraine is revealed by Bazyliuk and Kovalenko (1998), Varnaliy (2014). Dvoryaninov (2013) proposed the directions of Ukraine's economy unshadowing using the tax mechanisms. Mazur (2008) investigated the economy unshadowing as a priority of the economic security of Ukraine. Shevchenko and Reznik (2015) analyzed the issue of ensuring the state economic security within the area of taxation.

Dreher and Schneider (2010) analyze the influence of the shadow economy on the corruption and make hypothesis that they both are substitutes in the high income countries; their hypothesis has been tested in more than one hundred countries. Trebicka (2014) presents the connection between the formal and shadow economies. Using the economic and mathematical model, the scientist demonstrates the opportunity to obtain the accurate estimates regarding the size of the shadow economy. Hubareva, Chmutova, and Maksimova (2016) used in their paper a cognitive approach to model an impact of the destructive factors on the economic security at the macrolevel. Quintano and Mazzocchi (2016) carry out a comparative analysis of the EU shadow economy.

However, despite a considerable amount of the researches in this area, the economic and legal principles of the relations unshadowing in business activities and its impact on the economic security at the macrolevel are not satisfactorily detailed, which need the further scientific research.

The purpose of the article is to investigate the current status of the relations shadowing in business activities in Ukraine and abroad; find out the essence of the term 'the relations unshadowing in business activities', develop proposals which are aimed at improving the scientific approaches to the economic and legal principles of the relations unshadowing in business activities as a factor of an influence on the security at the macrolevel.

\section{METHODS}

The theoretical and methodological basis for solving the issue of the relations shadowing in business activities at the macrolevel is both theoretical provisions for the regulation of the economic processes, taking into account the safety factor, and the legal provisions ensuring the national and economic security. At the same time, it is necessary to address the dialectical principle in the study of the transdisciplinary economic and legal sphere of the relations, as well as use the following methods: the structural analysis and synthesis (with generalization of the security factors at the macroeconomic level, in particular, institutional, structural, program, strategic, financial, and investment factors); the monographic method (in the complex study of the factors that form a high level of the relations shadowing in business activity in Ukraine); the method of statistical analysis, table and graphic methods (in determining the areas of the corruption in countries around the world according to the criterion of the shadowing level of the business relations).

\section{RESULTS}

Assessing the current state of the shadow economy of Ukraine, one can confidently confirm that it creates a real threat for the national security and democratic development of the country (Varnaliy, 2014, p. 46). According to various estimates, the shadow turnover in Ukraine is $20-60 \%$ of GDP.

The Law of Ukraine "On the National Security" defines 'shadowing' of the national economy as one of the factors threatening the national interests and national security of the state (On the National Security of Ukraine (2003). Law of Ukraine of June 19, 2003 No. 964-IV).

Schneider (2010), Professor of the Johannes Kepler University Linz, whose calculations are used by the IMF and the World Bank, gives the data (Figure 1) 
Source: Schneider, Buehn, and Moutenegro (2010).

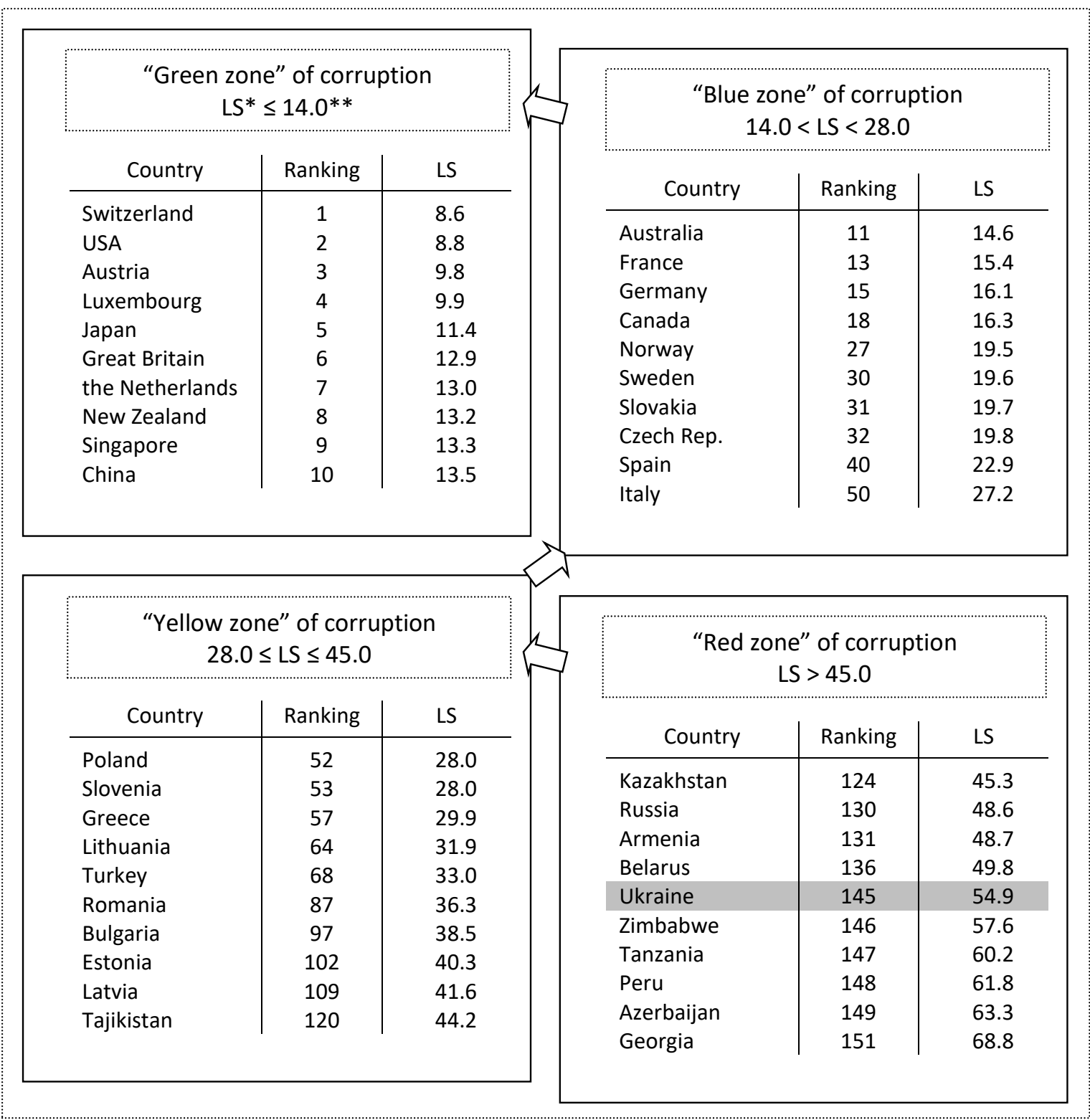

Notes: ${ }^{\star}$ Level of shadowing. ${ }^{* \star}$ Percentage of GDP.

Figure 1. Four 'colored' zones of corruption in some countries in the world according to the 'level of shadowing' as a percentage of GDP (based on Schneider's data, 2010)

on the shadowing level in GDP percentage on country as of 2011, where Ukraine ranks the 145th.

It can be concluded that the level of the shadow economy in the developed countries is approximately $15 \%$ of GDP and does not have a significant impact on the national security of the country.

Yurchyshyn, the director of the economic programs at Razumkov Center, determines the level of economy shadowing in Ukraine at $50 \%$ of GDP
(Iurchyshyn, 2013). The Ministry of the Economic Development and Trade estimates the level of the shadow economy in Ukraine at $45 \%$ of GDP (The Government Estimated the Size of the Shadow Economy in Ukraine (2013).

It is widely agreed that the level of $30-40 \%$ of the economy shadowing means a critical threshold, accessing of which provides the evidence of the existence of so-called reproducing system of the shadow economic relations in the state. 
One should agree that, now, under the political and economic instability in the country, a mass withdrawal of the capitals into the shadow by way of insuring against the risk of the business interruption and loss in income takes place, as a result, the level of the shadow relations in business activities quite naturally increases and reaches a level greater than 30 to $40 \%$ of GDP.

Obviously, this position of the state is not consistent with the course towards European integration, as the level of the shadow relations in business activities is significantly higher than in economically developed countries and most postSoviet countries. Especially, given the disappointing forecasts (Table 1), based on data up to 2016 . Therefore, Ukraine will be a country with a stable shadow economy in 2025 as in 2010 (Figure 1).

Table 1. Forecasts of the size of shadow economies (\% GDP) in some countries in the world according to 'colored' zones of corruption

Source: Emerging from the Shadows. The Shadow Economy up to 2025 (2017, pp. 11-13).

\begin{tabular}{|c|c|c|c|}
\hline \multirow{2}{*}{ Zone/Country } & \multirow{2}{*}{2016} & \multicolumn{2}{|c|}{ Forecasts } \\
\hline & & 2020 & 2025 \\
\hline \multicolumn{4}{|c|}{ "Green zone" } \\
\hline USA & 7.78 & 7.42 & 6.94 \\
\hline Japan & 10.08 & 9.42 & 7.86 \\
\hline China & 10.15 & 10.05 & 9.9 \\
\hline \multicolumn{4}{|c|}{ "Blue zone" } \\
\hline Australia & 11.40 & 10.24 & 8.89 \\
\hline Canada & 14.4 & 13.95 & 13.80 \\
\hline Italy & 26.32 & 26.56 & 26.37 \\
\hline \multicolumn{4}{|c|}{ "Yellow zone" } \\
\hline Poland & 23.68 & 22.95 & 22.13 \\
\hline Estonia & 28.48 & 28.09 & 26.46 \\
\hline Bulgaria & 29.93 & 29.56 & 29.56 \\
\hline \multicolumn{4}{|c|}{ "Red zone" } \\
\hline Russia & 39.07 & 39.37 & 39.30 \\
\hline Ukraine & 45.96 & 46.10 & 45.98 \\
\hline Azerbaijan & 67.04 & 56.73 & 58.38 \\
\hline
\end{tabular}

For the further research, it is necessary to find out the factors of the existence and essence of the shadow relations in business activities as a factor of influence on the national economy security.

In particular, as Varnaliy $(2014$, p. 49$)$ notes, the issue of the shadow economy is a global and historical phenomenon, which to some extent is peculiar to all social systems.
According to the established national scientific statements in the field of the national economy management, which detail the issues of the economic security, considering the recommendations to improve the enterprise management in the work by Shevchenko (2010), the component of the relations unshadowing in business activities should be integrated into the appropriate factors system as follows (Figure 2).

Firstly, in the center of the indicated field of research there is the national economy management with a focus on its two components - forecasting and management, and concerning the aspect - the economic and legal policy of the state. It is necessary to specially emphasize the regulatory policy that sets the rules and instruments for control of the business entities behavior.

Secondly, these factors of the national economy management are arranged into three groups, namely the institutional and structural factors of the economic security, program and strategically factors of the security management of the national economy, as well as related financial, investment, competitive, and innovation factors. Especially, it is necessary to take into account the importance of a link between the relations unshadowing in business activities and the factor of anti-crisis state policy that should be reflected in the Ukrainian programs of the social and economic development.

It should also be noted that the shadow economy exists in almost every country, but its size is largely determined by the economic order in this state: the volume of the shadow economy is negligible in the state with a strong power, better law-making basis and organized management and vice versa (Schneider, Buehn, \& Moutenegro, 2010, p. 6).

The shadow economy occurs when the actions of the power and regulatory structures of the state, individuals or their groups contradict the objective economic laws (Bazylyuk \& Kovalenko, 1998, p. 37).

In general, as Mazur (2008, p. 78) rightly pointed out, the shadow economy is an objective phenomenon that has always existed, starting with the establishment of the commodity and money relations and the introduction of the prohibitions and restrictions by the government, in other words 


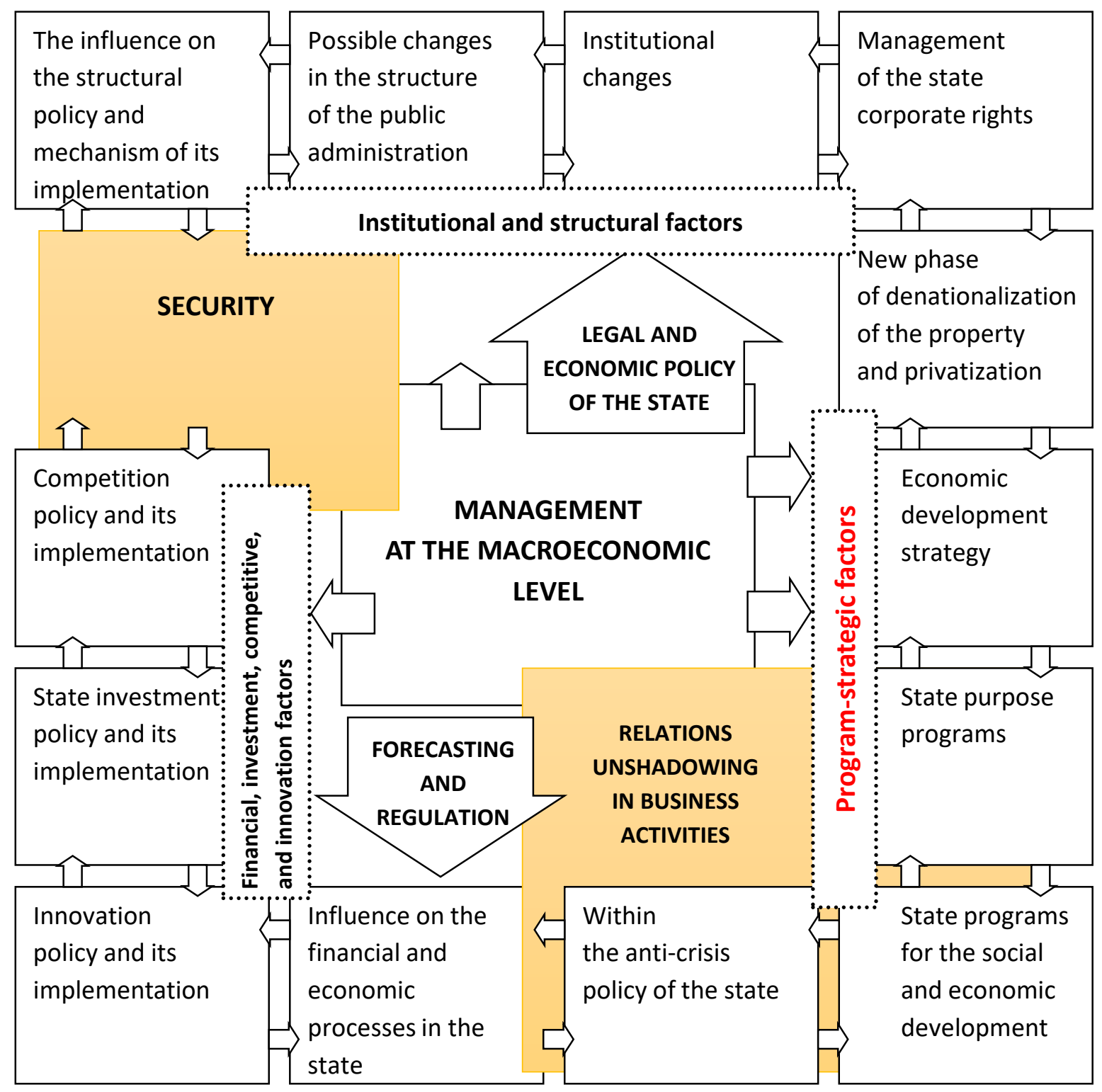

Figure 2. The relations unshadowing in business activities integrated into security factors within the management at the macroeconomic level

certain legislative and regulatory 'rules of the game' of the economic activities.

It is clear that the shadow economy as an objective phenomenon, cannot be overcome. The state needs by improving the legislative framework and efficient management significantly affect the factors, which form the high level of the shadow relations in business activities.

In our opinion, such factors include the following:

1) Imperfection of the regulatory and legal support, primarily, the administrative, economic, and labor legislation.

2) Ineffectiveness of the existing mechanisms of the state regulation of business activities.

3) Poor tax policy, which creates an additional burden on the taxpayers and leads to the evasion schemes.

4) Corruption in the government bodies, law enforcement, and judicial authorities.

5) Low effectiveness of the ongoing economic reforms. 
For effective influence on the mentioned factors, it is needed to find out the essence of the shadow relations in business activities.

It should be noted that at present, a unified approach to the definition of 'shadow economy' has not been formed.

The Ministry of Economy of Ukraine defines the essence of the shadow economy as economic activities of the entity, unregistered in accordance with the established procedure, which is characterized by the minimization of the costs for the production of goods, performance of works, provision of services, the evasion of taxes, duties (mandatory payments), the statistical survey, and presentation of statistical reporting, resulting in the violation of the statutory rules (level of minimum wage level, working time, conditions, and labor safety, etc.) (On Approval of Guidance Calculating the Shadow Economy Level, 2009).

The scientists provide a number of the definitions of this concept, but we should agree with Buhlak (2015) [12, p. 6], who defines the shadow relations in business activities as a set of the administrative, legal, financial, and economic relations unrecorded in the official statistics and uncontrolled by the public authorities: 1) legal relations, including informal and hidden ones; 2) illegal (unlawful) relations which arises while the entrepreneurs carry out the independent, initiative, and systematic activity at their own risk to achieve the economic and social results, safe conditions of work, and other requirements of the current legislation.

Accordingly, the relations unshadowing in business activities should be understood as the process of creating equal conditions and clear rules (as well as regulatory instruments for their implementation) of doing business, which motivate the entrepreneurs and other players in the market to shift from shadow to real economic activity.

It can be concluded from these definitions, that the shadow economy exists in the form of the administrative, legal, financial, and economic relations uncontrolled by the government. Therefore, logically, the next question arises: how can the state affect the relationships that it does not control? The answer should be obvious - by acting on that factors mentioned above, starting with the imperfection of the normative and legal support of business activities. But prior to proposing changes to the existing regulatory legislation, it is necessary to define the strategy of such changes not to cause even greater flow of business activities into the shadow sector.

Given the international experience, the regulatory framework has to be directed not at the punitive actions, but at providing favorable conditions for the legal economy development. The result of amending the current legislation in the sphere of business activities should be a flow of the shadow capitals into the legal sector of the economy.

According to the Global Financial Integrity's researches "Illegal Export of Capital from the Developing Countries', annually on average 11,676 billion dollars are illegally exported from Ukraine, over 10 years - respectively 116,762 billion dollars (More than 116 billion Dollars WERE Illegally Exported from Ukraine for 10 Years, 2015). At the same time, according to Mazur, the largest volumes of foreign investments into the Ukrainian economy are mainly domestic money, returned from abroad. They were obtained in the shadow business and capitalized in the official economy under the guise of the foreign investment (Mazur, 2008). Therefore, in our opinion, the state should carry out economic 'amnesty' by legislative enactment. In this sense, it would be advisable to refer to the foreign experience, in particular: the practice of economic 'amnesty' in the United States during 1980s and 1990s, when most states were exempted from the sanctions by the individuals who concealed income; the amnesty of 1988 in Ireland, which resulted in the accumulated funds exceeding the budget deficit; the amnesty of 1986 in France, which significantly increased the volume of the investments, etc. (Lopashenko, 2003, p. 142).

Such a legal act can be the Law 'On the Legalization of Funds Received in Non-Criminal Way'. This law should regulate the legal procedure and conditions of legalization, give the definition of a criminal and non-criminal capital, provide for the encouragement of the use of funds that are legalized, as well as provide guarantees of non-persecution of the legalization entities. 
In this aspect, an urgent solution to the issue of achieving the optimal balance of the public and private interest in the entrepreneurship field is needed. It can be solved by adopting a single legislative act on the state control in the entrepreneurship field, which should clearly regulate the general principles of such control. The basis of this law should be the principles of the deregulation of the business activities based on the market mechanisms, simplification of the conciliation and permitting the procedures for business, and transition from the penal sanctions to the incentive benefits.

The purpose of adopting such legislative acts in the areas of the administrative, economic, and labor law should be motivation of the entrepreneurs to unshadow their activities by their own.

Today, the number of the state entities of relations unshadowing in business activities is very significant: the President of Ukraine; the Verkhovna Rada of Ukraine (including the Committee on Industrial Policy and Entrepreneurship, the Committee on Economic Policy, the Committee on Financial Policy and Banking, the Committee on Taxation and Customs Policy); the Cabinet of Ministers of Ukraine; the ministries and other central executive authorities (the Ministry of Economic Development and Trade, the Ministry of Finance, the Ministry of Justice, the Ministry of Internal Affairs, the State Financial Monitoring Service, the State Fiscal Service, the State Regulatory Service, etc.); the National Bank of Ukraine, the National Commission on Securities and Stock Market, the National Commission, which carries out the state regulation in the field of the financial services markets; other state bodies and services; and the local governments. Instead, the division of functions and tasks between them precisely in the field of the economy unshadowing is not clearly defined in the legislation, which leads to the duplication of the powers, reducing the effectiveness of their activities aimed at the relations unshadowing in business activities and requires the appropriate optimization measures.

Such measures could be the implementation of an independent examination of the existing laws and regulatory legal acts of the ministries, departments, and local authorities for their bringing to a certain system, the elimination of duplication, reduction, and impact on the functioning of the shadow economy.

As Dvorianinov (2013, p. 153) rightly notes, it is possible to allocate one uniform mechanism, acceptable for unshadowing in all sectors of the economy among others, namely tax mechanisms, as taxes and tax system cover all economic spheres.

There is no doubt that now the necessity in reformation of the taxation system has acquired an extreme importance, because it is unacceptable either for businessmen or for the state. The main purpose of the reform should be the creation of the prerequisites for economic growth. However, during the reformation of the tax system, in our opinion, it must be taken into account whether such changes fill up the budget, or on the contrary contribute to the emergence of new schemes for tax evasion. In addition, the entrepreneurs who use the general tax system more often complain of the burdensome and arbitrary tax administration. Therefore, the priority of the fiscal authorities' activity is to work with non-taxpayers, as it happens in EU countries, and not with law-abiding taxpayers.

The tax reform should make the rules of the taxation game equal, transparent, and fair and it should reduce the burden on the honest taxpayers due to a uniform distribution of the tax burden as well as simplify the tax administration.

It should be noted that the tax service is one of the main hotbeds of the corruption, which, of course, does not indicate its absence in other government, law enforcement, and judiciary authorities. Obviously, it is impossible to deny that the corruption is endemic for all countries, regardless of the political system or the economic development level. But the fact that corruption has become almost the hallmark of Ukraine in the world, put this question in the first line of the largest and most painful issues of the Ukrainian reality (Is it Possible to Prevent Corruption in Ukraine? 2012).

Today, issues on corruption are associated with the start of functioning of the National Anti-Corruption Bureau and Anti-Corruption Prosecutors Office, the development of the National 
Agency on Corruption Prevention and the National Agency for the Investigation and Disposal of Assets. In our view, effective corruption prevention in the sense of the relations unshadowing in business ac- tivities primarily depends on the structural changes in the existing regulatory legislation aiming at its real and radical simplification, independence from the officials' abuse of power.

\section{CONCLUSION}

As a result of the research the current state of the relations unshadowing in business activities in Ukraine was analyzed. It was found that Ukraine is in a dangerous so-called red zone of corruption. The essence of the shadow economy and sources of its emergence were also considered, and the question of creating a sensitive system of the economic incentives aimed at the economic activity unshadowing was put. It is proved that it is impossible to accurately assess the extent of the shadow economy at present moment. Based on the research carried out, the ways to improve this issue were proposed, in particular through the introduction of the changes to the existing regulatory legislation of Ukraine. The relations unshadowing in business activities is integrated into the factors ensuring the national economy safety at the macrolevel, namely the institutional and structural factors: the influence on the structural policy and mechanism of its implementation, possible changes in the structure of the public administration, institutional changes, management of the state corporate rights, and new phase of the denationalization of property and privatization; program and strategic factors: economic development strategy, state purpose programs, and state programs for the social and economic development; financial, investment, competitive, and innovation factors: competition policy and its implementation, state investment policy and its implementation, innovation policy and its implementation, and the influence on the financial and economic processes in the state.

We further plan to analyze forecasting and state regulation processes within the issues of the shadow economy in the Ukrainian regions.

\section{ACKNOWLEDGEMENT}

An article is prepared in the frames of the project for the young scientists of Ukraine No 0116U006814 dated August 19, 2016 (01/15-06/3278) "Improvement of the System of Law Enforcement Bodies to Provide the Financial and Economic Security of Ukraine".

\section{REFERENCES}

1. Bazylyuk, A. V., \&

Kovalenko, A. V. (1998). Shadow

Economy in Ukraine. Kyiv: NDEI

Minekonomiky Ukrainy [in Ukr.].

2. Dreher, A., \& Schneider, F. (2010). Corruption and the Shadow Economy: an Empirical Analysis. Public Choice, 144(1), 215-238. https://doi.org/10.1007/ s11127-009-9513-0

3. Dvoryaninov, A. V. (2013). Directions of Economy Unshadowing of Ukraine through the Use of tax Mechanisms. Finansovyi Prostir (Financial Space), 4(12), 151-156.
4. The Association of Chartered Certified Accountants (2017). Emerging from the Shadows. The Shadow Economy up to 2025. Retrieved from http://www.accaglobal.com/ content/dam/ACCA_Global/ Technical/Future/pi-shadoweconomy-report.pdf

5. Hubareva, I., Chmutova, I., \& Maksimova, M. (2016). Ukrainian Economy Unshadowing as a Factor of the State Economic Security Management. Economic AnnalsXXI, 159(5-6), 25-28. https://doi. org/10.21003/ea.V159-05

6. Is it Possible to Prevent Corruption in Ukraine? (2012). Retrieved from http://www.pravda.com. ua/inozmi/svoboda/2012/07/10/ 6968483/?attempt=1

7. Iurchyshyn, V. (2013). Expert: 50 \% Ukraine's Economy is in a "Viscous Swamp" of the shadow. Retrieved from http://m.tyzhden. ua/News/84195

8. Lopashenko, N. A. (2003). The Escape of Capital from Russia and Its Return. Human resources. Moscow: Business-school "IntelSynthesis".

9. Mazur, I. I. (2008). Economy Unshadowing as a Priority of Economic Security of Ukraine. 
Stratehichni Priorytety (Strategic Priorities), 3(8), 76-83.

10. More than 116 billion Dollars WERE Illegally Exported from Ukraine for 10 Years (2015). Retrieved from http://glavcom.ua/ news/346536.html

11. On Approval of Guidance Calculating the Shadow Economy Level (2009). Order of the Ministry of Economy of Ukraine of Febr. 18, 2009 No. 123. Retrieved from https://www. me.kmu.gov.ua\%2Ffile\%2F135879 $\% 2 \mathrm{FmbWeYS} 3 \mathrm{i}-$

fOTFw\&bvm=bv.85970519,d. ZWU

12. On National Security of Ukraine (2003). Law of Ukraine of June 19, 2003 No. 964-IV. Vidomosti Verkhovnoi Rady Ukrainy (Collected Legislation of Ukraine's Verkhovna Rada), 39(Art. 351).

13. Quintano, C., \& Mazzocchi, P. (2016). A Comparative Analysis in the EU Shadow Economy Using a DEA Model. Global Business and Economic Review, 18(3-4), 445-468. https://doi.org/10.1504/ GBER.2016.076255

14. Schneider, F., Buehn, A., \& Moutenegro, C. (2010). Shadow Economies All Over the World. Retrieved from http://lsfiwi.wiso. uni-potsdam.de/projekte/schattenwirtschaft/Working\%20Group $\% 20$ 7/03\%20Buehn_Schneider_Shadow_Economies_potsdam2010.pdf.

15. Shevchenko, H. M. (2010). The Business Management in the Context of the Organizational Development. Visnyk Sumskoho Derzhavnoho Universytetu. Seriya Ekonomika (Bulletin of Sumy State University. Series Economy), 2, 63-72.

16. Shevchenko, H. M., \& Reznik, O. M. (2015). Ensuring the State Economic Security in the Area of Taxation: AgentBased and Subject-Based Legal Approaches. Actual Issues of the Economics, 6(168), 167-172.
17. The Government Estimated the Size of the Shadow Economy in Ukraine (2013). Retrieved from http://ua-ekonomist.com/2420-vuryad-pdrahuvali-rozmr-tnovoyiekonomki-v-ukrayin.html

18. Trebicka, B. (2014). Mimic Model: a Tool to Estimate the Shadow Economy. Academic Journal of International Studies, 3(6), 295-300. https://doi.org/10.5901/ ajis.2014.v3n6p295

19. Varnaliy, Z. S. (2014). Theoretical Principles of the Economy Unshadowing in Ukraine. Visnyk Vinnytskoho Politekhnichnoho Instytutu (Bulletin of Vinnytsya Polytechnic Institute), 1, 46-53.

20. Williams, C. C., \& Horodnic, I. A. (2015). Explaining and Tackling the Shadow Economy in Estonia, Latvia and Lithuania: a Tax Morale Approach. Baltic Journal of the Economics, 15(2), 81-98. https://doi.org/10.1080/140609 9X.2015.1114714 